\title{
Pengembangan Model Kepemimpinan Kepala Sekolah yang Efektif
}

\author{
La Ode Mane Mbeu dan Anwar \\ SMAN 1 Konda dan FKIP/PPs Unhalu
}

\begin{abstract}
Abstrak: Penelitian ini bertujuan untuk: 1) untuk mendapatkan sebuah model kepemimpinan kepala sekolah yang efektif sesuai dengan kondisi SMP Negeri di Kecamatan Konda dan 2) untuk mendapatkan gambaran keefektifan pilar entrepreneur, teladan, cerdas dan demokratis dalam implementasi kepemimpinan kepala sekolah efektif di SMP Negeri Kecamatan Konda. Hasil penelitian dan pengembangan menunjukkan bahwa: 1) model kepemimpinan kepala sekolah yang efektif sesuai dengan kondisi di SMP Negeri se-Kecamatan Konda adalah kepemimpinan entrepreneur, teladan, cerdas dan demokratis (ENTELCERDS) dan 2) efektivitas implementasi kepemimpinan kepala sekolah efektif di SMP Negeri se-Kecamatan Konda terkait dengan: (a) Entrepreneur secara rerata berkualifikasi cukup efektif, (b) Keteladanan secara rerata berkualifikasi cukup efektif; (c) kecerdasan secara rerata berkualifikasi efektif, dan (d) demokratis secara rerata berkualifikasi sangat efektif.
\end{abstract}

Kata kunci: model kepemimpinan, kepala sekolah efektif, entrepreneur, teladan, cerdas dan demokratis

\begin{abstract}
The aim of this study are: 1 ). To find an appropriate model of principal leadership conducting a pilot in public junior high schools in Konda sub-District; 2). To find out the description of the NEM paradigm of principal leadership concept; which include entrepreneurship skill, good role model, capable and democratic in implementing the leadership skill as a principal. The result of this study describes; 1 ). The model of principal leadership skill besed on the public junior high school in Konda, which include entrepreneur skill, good role model, capable and democratic, and 2) the description of the result of the head master leadership skill including; a) entrepreneur skill is moderate; b) good role model is moderate; c) capability is effective; d) democracy is very effective.
\end{abstract}

Key note: the development of the principal leadership model based on the entrepreneurship skill, good role model, capability and democratic

\section{Pendahuluan}

Terdapat enam hal mendasar yang melatarbelakangi penelitian ini yaitu: 1) Salah satu komponen penting di sekolah yang cukup berpengaruh pada proses dan hasil pendidikan adalah kepala sekolah dengan kepemimpinannya; 2) Kepemimpinan kepala sekolah yang efektif akan dapat mewujudkan sekolah yang efektif yang antara lain terukur melalui prestasi akademik dan nonakademik; 3) Di masyarakat masih sering terdengar adanya keluhan mengenai kepemimpinan kepala sekolah yang tidak bermutu, tidak efektif dan masih banyak tindakan siswa yang bertentangan dengan tujuan pendidikan seperti tawuran, disiplin rendah dan akhlak yang tidak terpuji; 4) Di era MBS Kepala Sekolah dituntut agar kepemimpinannya tidak hanya sekedar sebagai leader akan tetapi ia harus mampu tampil sebagai enterpreneur, teladan, cerdas cendekia dan demokratis; 5) sering berubahnya tugas dan kompetensi kepala sekolah dari EMASLIM (Edukator, Manajer, Administrator, Supervisor, Leader, Inovator dan Motivator) menjadi PMPAWPP (Pemimpin, Manajer, Pendidik, Administrator, Wirausahawan, Pencipta Iklim Kerja dan Penyelia, selanjutnya berubah lagi menjadi PWKS (Profesional, Wawasan kependidikan, Kepribadian dan Sosial), kemudian menjadi KMWSS (Kepribadian, Manajer, Wirausahawan, Supervisor dan kompetensi SoSial serta dibuplikasikannya gagasan tentang peran utama dan kompetensi kepala sekolah SASETO (Statesperson leadership, Administratif leadership, Supervisory leadership, Educational leadership, Team leadership and Organization leadership), merupakan bentuk keseriusan pemerintah dan masyarakat secara nasional termasuk di Kecamatan Konda untuk segera menemukan satu model kepemimpinan 
kepala sekolah efektif di sekolah; dan 6) Dampak buruk pengangkatan kepala sekolah di era otonomi daerah yang tidak mengacu pada ketentuan Kepmendiknas No.162/U/2003 perlu diimbangi dengan usaha penemuan satu model kepemimpinan kepala sekolah efektif yang dijadikan sebagai panduan di sekolah yang dipimpinnya. Temuan penelitian Heineman \& Luxly yang dipublikasikan oleh Supriadi (1998: 347) bahwa 30\% varians mutu di sekolah ditentukan oleh kepemimpinan kepala sekolah. Dengan demikian, kepemimpinan kepala sekolah yang efektif perlu direvitalisasi melalui pengkajian sesuai prosedur ilmiah termasuk di Kecamatan Konda.

Permasalahan yang menjadi fokus kajian dirumuskan sebagai berikut: 1) Bagaimanakah model kepemimpinan kepala sekolah yang efektif dalam pengelolaan sekolah sesuai dengan kondisi SMP Negeri di Kecamatan Konda? 2) Bagaimanakah gambaran keefektifan pilar entrepreneur, teladan, cerdas dan demokratis pada kepemimpinan kepala sekolah yang efektif sesuai dengan kondisi SMP Negeri di Kecamatan Konda?

Tujuan penelitian yaitu untuk: 1) mendapatkan sebuah model kepemimpinan kepala sekolah yang efektif dalam mengelola sekolah yang tidak hanya dapat diterapkan pada SMP Negeri di Kecamatan Konda, akan tetapi dapat menjadi salah satu pilihan untuk memperbaiki efektifitas kepemimpinan kepala sekolah di Kabupaten Konawe Selatan dan Provinsi Sulawesi Tenggara pada umumnya; dan 2) memperoleh gambaran tentang keefektifan pilar entrepreneur, teladan, cerdas dan demokratis dalam kepemimpinan kepala sekolah yang efektif sesuai dengan kondisi SMP Negeri di Kecamatan Konda.

\section{Kajian Literatur}

Pengembangan diartikan sebagai suatu proses yang berkaitan dengan upaya memperbaiki, memperluas, memajukan atau memperbaiki ke arah yang dikehendaki (Anonim, 2002: 538). Sedangkan Mutohir (2007: 69) menyatakan bahwa pengembangan adalah proses yang berkesinambungan, yang dimulai dari tahap pengembangan konsep, metodologi hingga implementasi.

Dinyatakan oleh Anwar (2007: 50) bahwa pengembangan adalah upaya memperluas atau mewujudkan potensi-potensi, membawa suatu keadaan secara bertingkat kepada suatu keadaan yang lebih lengkap, lebih besar atau lebih baik, memajukan sesuatu dari yang lebih awal kepada yang lebih akhir atau dari yang sederhana kepada tahapan perubahan yang lebih kompleks. Berdasarkan konsep pengembangan dari pandangan di atas, dapat disarikan intinya bahwa yang dimaksud dengan pengembangan dalam dimensi model kepemimpinan kepala sekolah adalah suatu proses usaha memperbaiki ke arah yang lebih baik dan efektif. Pengembangan juga mengandung arti sebagai proses pemampuan dan pemberdayaan untuk dapat melihat dan memanfaatkan peluang-peluang yang terbuka demi meraih kehidupan yang berdaya saing sehat dan sejahtera (Tilaar, 2001: 414). Dengan demikian, maka pengembangan kepemimpinan dapat juga diartikan sebagai proses pemberdayaan pemimpin dengan memberikan kemampuan tertentu sehingga pola dan aktivitas kepemimpinan yang diterapkannya dapat berhasil guna dan berdaya guna.

Konsep model di dalamnya terkandung beberapa makna tergantung pada kata yang mengikutinya. Untuk meminimalisasi pengertian ganda dari kata model tersebut, maka dalam kaitan dengan penelitian ini model diartikan sebagai pola atau contoh acuan (Anonim, 2002: 751). Jika makna konsep model tersebut dikaitkan dengan kepemimpinan maka arti yang dikandungnya adalah pola yang ditampilkan seorang pemimpin di dalam melaksanakan tugas kepada yang dipimpinnya. Model diartikan juga sebagai bentuk dan pola (Moleong, 2000: 236). Berdasarkan dua pemaknaan terhadap model di atas, dapat dinyatakan bahwa model ke-pemimpinan adalah pola atau bentuk tampilan seorang pemimpin dalam melaksanakan tugas dan fungsinya pada suatu lembaga atau organisasi. Dengan demikian, maka model kepemimpinan kepala sekolah adalah pola atau bentuk tampilan kepala sekolah yang menggambarkan kompetensi yang dimilikinya untuk mengelola sekolah sehingga mencapai hasil optimal.

Kata efektif berarti dapat membawa hasil atau berhasil guna. Dengan demikian, kepemimpinan kepala sekolah yang efektif berarti kepemimpinan yang dapat mencapai hasil yang optimal. Keoptimalan pencapaian hasil kepemimpinan kepala sekolah tidak terlepas dari peran dan tanggung jawabnya sebagai pemimpin 
pendidikan yang oleh Sergiovanni membaginya atas 6 kompetensi yaitu: statesperson leadership, educational leadership, organizational leadership, administrative leadership, supervisory leadership and team leadership (Mantja, 2008: 3). Untuk meraih hasil yang optimal, maka diperlukan empat kemampuan penyangga kepemimpinan kepala sekolah yang tidak hanya mengakomodir kompetensi kepala sekolah sebagaimana yang disebutkan di atas melainkan juga unsur-unsur krusial lainnya yakni entrepreneur, teladan, cerdas dan demokratis serta lima layanan yang harus diwujudkan oleh kepala sekolah agar pelanggan puas yaitu tepati janji (reliability), mampu menjamin kualitas pembelajaran (assurance), iklim sekolah yang kondusif (tangible), mencurahkan perhatian penuh pada peserta didik (emphaty) dan cepat tanggap terhadap kebutuhan peserta didik (responsiveness) (Aksi, 2007: 7). Hal ini berarti bahwa untuk mencapai kepemimpinan yang efektif di sekolah, kepala sekolah harus mampu mencurahkan dan pelanggan dengan mengedepankan kemampuan entrepreneur, teladan, cerdas dan demokratis.

Mengacu pada uraian di atas menunjukkan bahwa kepemimpinan kepala sekolah tidak hanya sekedar sukses tetapi juga harus efektif yang ditandai oleh kemampuannya mempengaruhi orang lain untuk bergerak menuju tujuan tanpa merasa terpakasa. Hal ini diterangkan oleh Blanchard bahwa if managers a both succsessful and efective, their influence tend to lead to long run productivity and organization development (Syafaruddin, 2002: 62). Pandangan ini mendeskripsikan bahwa kepemimpinan kepala sekolah yang efektif perlu ditunjang oleh kemampuan kepala sekolah sebagai entrepreneur, sebagai teladan, sebagai pribadi yang cerdas, dan sebagai sosok yang demokratis.

Menurut Rivai (2008: 38) bahwa pemimpin yang fektif memiliki sejumlah kriteria yaitu: 1) jujur, 2) taqwa terhadap Tuhan Yang Maha Esa, 3) memiliki integritas, 4) memiliki vitalitas fisik dan mental, 5) memiliki kecerdasan, 6) memiliki kearifan, 7) bertanggung jawab, 8) kompeten, 9) memahami kebutuhan pengikutnya, 10) memiliki keterampilan interpersonal, 11) memiliki kebutuhan akan prestasi, 12) mampu memotivasi dan memberi semangat, 13) mampu menyelesaikan masalah, 14) memiliki kemampuan untuk meyakinkan, 15) memiliki kapasitas untuk menang,
16) memiliki kapasitas untuk mengelola, memutuskan, menentukan perioritas, 17) mampu memegang kepercayaan, 18) memiliki pengaruh, 19) mampu beradaptasi dan 20) memiliki fleksibilitas. Pandangan ini menunjukkan bahwa kepemimpinan kepala sekolah yang efektif adalah kepemimpinan entrepreneur, teladan, cerdas dan demokratis yang tergambar melalui kriteria-kriteria di atas.

Sehubungan dengan itu, ada pula formulasi lain yang menekankan pada keterampilan sehingga seorang kepala sekolah dapat efektif dalam memimpin sebagai berikut: 1) keterampilan teknis seperti TIK, 2) keterampilan hubungan manusia seperti kemampuan untuk memberikan bantuan kepada orang lain baik individu maupun kelompok, 3) keterampilan konsepsional seperti merangkum ide/gagasan, 4) keterampilan pendidikan dan pengajaran, 5) keterampilan kognitif seperti pengetahuan intelektual, serta 6) memiliki komitmen, integritas dan proaktif (Subagioatmodiwirio, 2000: 162). Jika keterampilan dimaksud dikelompokkan, maka keterampilan teknis termasuk keentrepreneuran, keterampilan membangun hubungan, memberikan bantuan kepada orang lain, keterampilan konsepsional dan keterampilan kognitif dicakup oleh kecerdasan, memiliki komitmen, integritas dan proaktif dicakup oleh keteladanan dan demokratis.

Apabila dicermati secara saksama keterampilan yang menjadi indikator kepala sekolah efektif, jelaslah bahwa keenam keterampilan tersebut telah dirangkum dalam 4 dimensi utama model kepemimpinan kepala sekolah yang efektif melalui indikatornya masing-masing. Dengan demikian, maka dapat dinyatakan bahwa kepemimpinan kepala sekolah yang efektif harus terukur melalui adanya kemampuan sebagai entrepreneur, sebagai panutan, sebagai pribadi cerdas dan sebagai sosok demokratis.

Berdasarkan uraian tersebut, menunjukkan bahwa kepemimpinan adalah suatu konsep manajemen dalam kehidupan organisasi yang mempunyai kedudukan strategis dan merupakan gejala sosial yang selalu diperlukan dalam kehidupan kelompok. Pendapat ini mengandung makna bahwa kepemimpinan dalam suatu organisasi seperti sekolah sangat diperlukan karena memiliki kedudukan yang sangat strategis dan memiliki peran sentral dalam mengefektifkan 
organisasi dalam rangka pencapaian tujuannya. Senada dengan ulasan tersebut Suderadjat (2005: 121) menyatakan bahwa kepemimpinan pendidikan seorang kepala sekolah merupakan tumpuan keberhasilan manajemen peningkatan mutu berbasis sekolah. Dari pendapat ini dapat dijelaskan bahwa manajemen apapun yang akan diterapkan dalam satu satuan pendidikan tidak akan mencapai hasil optimal jika kepemimpinan yang diaplikasikan bukan mengacu pada model kepemimpinan yang efektif.

Sehubungan dengan pandangan tersebut, ada yang menekankan bahwa kepemimpinan sekolah merupakan inti atau ujung tombak pendidikan Indonesia (Soebagioatmodiwirio, 2000: 161). Hal ini berarti bahwa kepemimpinan kepala sekolah sangat penting dalam segala aspeknya, sehingga perlu dikembangkan ke arah yang lebih baik dan efektif agar kualitas pendidikan di Indonesia dapat lebih baik di masamasa yang akan datang.

Mencermati pentingnya kepemimpinan kepala sekolah, seperti tersebut di atas, maka Nurkolis (2003: 162) mengajukan karakteristik kepemimpinan kepala sekolah yang efektif, yaitu: 1 ) dapat beradaptasi dengan situasi 2) peka terhadap lingkungan sosial, 3) ambisius serta berorientasi pada hasil, 4) tegas, 5) dapat bekerjasama dengan orang lain, 6) meyakinkan 7) mandiri, 8) mampu mempengaruhi orang lain, 9) energik, 10) tekun, 11) percaya diri, 12) tahan stres dan 13) memiliki tanggung jawab. Sementara keterampilan yang dimilikinya antara lain cerdas, terampil secara konseptual, kreatif, diplomatis dan taktis, lancar berbahasa, memiliki pengetahuan terhadap tugas kelompok, mampu mengorganisasi, mampu mempengaruhi, dan meyakinkan serta memiliki keterampilan sosial.

Senada dengan itu, Wahyudi (2009: 129) menyatakan bahwa kepemimpinan kepala sekolah yang efektif adalah kepemimpinan tiga dimensi (tugas, prilaku, keefektifan) secara situasional dengan gaya instruktif, konsultatif, partisipatif dan delegatif sesuai dengan tingkat kematangan dari stafnya atau guru-guru. Hal ini menunjukkan bahwa gaya kepemimpinan instruktif diberikan kepada guru yang tidak mampu dan tidak berani memikul tanggung jawab, gaya kepemimpinan konsultatif diterapkan kepada guru yang tidak mampu tetapi mau mengambil tanggung jawab, gaya kepemimpinan partisipatif diterapkan kepada guru yang memiliki kemampuan tetapi memiliki keraguan dan gaya kepemimpinan delegatif diberikan kepada guru yang mampu dan mau memikul tanggung jawab.

Secara empiris ditemukan hasil penelitian yang dilakukan oleh Akil (2006: 24) bahwa kepemimpinan kepala sekolah berpengaruh terhadap prestasi belajar siswa. Berdasarkan teori, konsep dan temuan empiris tersebut, maka pengembangan model kepemimpinan kepala sekolah yang efektif cukup strategis untuk dikajikembangkan, karena salah satu komponen yang urgen untuk mengembangkan mutu sekolah adalah peran kepemimpinan kepala sekolah. Artinya, untuk menghasilkan sekolah yang efektif atau berkinerja baik, maka kepemimpinan kepala sekolah yang efektif menjadi suatu keharusan untuk dikembangkan.

\section{Metode Penelitian Pengembangan}

Penelitian ini dilaksanakan pada semua SMP Negeri di Kecamatan Konda Kabupaten Konawe Selatan yang dilaksanakan sejak bulan September 2008 hingga bulan April 2009. Dipilihnya SMP Negeri di Kecamatan Konda sebagai lokasi penelitian oleh karena selain pertimbangan teknis seperti ketersediaan data yang diperlukan juga karena SMP Negeri di Kecamatan Konda mewakili karakteristik dari kebanyakan SMP Negeri di Kabupaten Konawe Selatan yakni terkategori Sekolah Standar Nasional, Sekolah potensial dan sekolah terpelosok.

Penelitian ini termasuk jenis penelitian dan pengembangan yang secara konseptual dipandang sebagai suatu proses untuk mengembangkan dan memvalidasi produk pendidikan. Konsep seperti ini dipertegas oleh Borg \& Gall (1989: 782) bahwa penelitian pengembangan adalah suatu proses untuk mengembangkan dan memvalidasi suatu produk pendidikan. Dengan demikian, inti dari penelitian ini adalah persiapan, pelaksanaan desain model yang akan dihasilkan, validasi dan revisi serta tindakan.

Pengembangan model kepemimpinan kepala sekolah ini secara metodologis mengadaptasi Borg \& Gall (1989: 784); Sukmadinata, (2005: 170); dan Sugiono (2007: 298) sehingga langkah pengembangan model dimaksud sebagai berikut: Pertama, identifikasi potensi dan masalah, pada tahap ini peneliti menggali informasi yang potensial untuk dikembangkan dan menelaah 
kondisi ril saat ini terkait dengan kepemimpinan kepala sekolah sebagai sumber masalah.

Kedua, pengumpulan data dan informasi yang diperlukan untuk merencanakan produk model konseptual, pada tahap ini peneliti mengumpulkan berbagai informasi yang dapat dijadikan bahan untuk perencanaan produk model tertentu (rencana draf model) yang diharapkan dapat mengatasi masalah yang ada seperti yang digambarkan pada tahap pertama.

Ketiga, desain produk adalah rancangan konseptual model yang akan dihasilkan. Pada tahap ini peneliti merancang model kepemimpinan efektif yang dengan berbagai pilar dan indikatornya sesuai dengan pengalaman atas realitas kepemimpinan selama ini serta mengkaji referensi mutakhir yang relevan sebagai pendukungnya.

Keempat, validasi desain yaitu pada tahap ini peneliti melakukan kegiatan mendatangi target sasaran terutama di luar dari sasaran penelitian yang sebenarnya untuk diminta penilaian dan tanggapannya terhadap desain model konseptual kepemimpinan kepala sekolah efektif lewat diskusi terbatas yang diawali dengan presentasi mengenai proses penelitian hingga menghasilkan desain dengan keunggulannya.

Kelima, perbaikan desain adalah revisi terhadap kelemahan desain produk baru setelah dinilai oleh para pakar dan praktisi serta birokrat pendidikan. Pada tahap ini peneliti merevisi dan memperbaiki segala kelemahan model produk baru.

Keenam, uji coba terbatas produk adalah uji coba terbatas setelah adanya revisi atas dasar penilaian dan masukan para pakar, praktisi dan birokrat yang telah disebutkan di atas. Pada tahap ini peneliti mengujicobakan produk model baru sesuai target group secara terbatas dengan tujuan untuk mendapatkan masukan dan informasi apakah model kepemimpinan tersebut akan lebih efektif dibanding dengan model kepemimpinan kepala sekolah sebelumnya.

Ketujuh, revisi produk/model baru dari hasil uji coba terbatas. Pada tahap ini peneliti melakukan kegiatan perbaikan terhadap hal-hal yang belum sesuai dengan kriteria produk model kepemimpinan kepala sekolah efektif yang diharapkan.

Mempertimbangan masalah teknis, maka dalam penelitian pengembangan ini dibatasi hanya sampai pada langkah ketujuh yakni revisi produk dan berakhir dengan produk hasil pengembangan. Hal ini dimungkinkan secara metodologis sebab Rothwell, (1995: 48) menyatakan bahwa model-model untuk pengembangan dapat dimulai dengan tahap sebagai berikut: Plan, Do, Check, and Act Cycle, and Action Research. Demikian juga Sukmadinata (2005: 184) menyatakan bahwa tahap-tahap penelitian dan pengembangan dari Borg dan Gall dapat dimodifikasi sebagai berikut: 1) Studi Pendahuluan, 2) Pengembangan Model dan 3) Uji Model. Hal ini menunjukkan bahwa penelitian pengembangan model kepemimpinan kepala sekolah efektif dapat disederhanakan prosedurnya yakni perencanaan, penyusunan draft, perbaikan/revisi/ validasi secara bersiklus dan tindakan/uji model untuk menghasilkan produk konseptual dan produk hasil uji coba tetapi tidak menghilangkan substansi dari langkah-langkah yang telah diketengahkan di atas.

Subjek penelitian ini terbagi atas dua kelompok yaitu subjek validasi model konseptual dan subjek uji coba terbatas. Subjek validasi model konseptual 30 orang, terdiri dari 2 orang pakar manajemen pendidikan, 3 orang pejabat birokrat pendidikan, 3 orang anggota Dewan Pendidikan Kabupaten, 3 orang Kepala Sekolah, 2 orang Pengawas, 11 orang guru, 6 orang pengurus Komite Sekolah. Sedangkan subjek uji coba terbatas terdiri dari 3 orang kepala sekolah, 1 orang pengawas ditambah dengan 12 orang guru di SMP Negeri se-Kecamatan Konda sehingga berjumlah 16 orang. Untuk mendapatkan subjek penelitian seperti itu, maka penetapan sampel dilakukan secara purposive sampling (Sugiyono, 2007: 218; Riyanto, 2001: 80) sebab penelitian ini memiliki tujuan khusus dan sampel itulah yang dipandang cukup mengetahui tentang apa yang diharapkan.

Pengumpulan data dalam penelitian pengembangan ini menggunakan teknik non tes berupa: 1) Angket yakni sejumlah pertanyaan atau pernyataan yang dikembangkan sendiri oleh peneliti untuk menjaring data tentang efektif tidaknya model kepemimpinan kepala sekolah yang dikembangkan (uji validasi model konseptual dan uji coba terbatas model); 2) Diskusi terfokus, adalah kegiatan peneliti dalam usaha menjaring data pelengkap dari target group sehingga data yang diperoleh dalam penelitian pengembangan ini terkategori lengkap. Target group dimaksud 
adalah Ahli Manajemen Pendidikan, Birokrat Pendidikan dan Praktisi Pendidikan yang telah disebutkan di atas (validasi model konseptual); 3) Wawancara adalah instrumen penjaring data pelengkap terkait dengan uji coba terbatas model; 4) Pengamatan adalah instrumen penjaring data pelengkap terkait dengan uji coba terbatas model.

Teknik analisis data yang digunakan adalah analisis deskriptif kuantitatif dengan menggunakan rumus persentase (Arikunto, 2001: 236 dan Sugiyono, 2004: 32). Demikian pula uji validitas instrumen digunakan analisis statistik inferensial.

Pemberian makna dalam pengambilan keputusan terkait dengan revisi draf model pengembangan kepemimpinan kepala sekolah yang efektif, peneliti menggunakan tabel penafsiran data dan tindak lanjut validasi produk pengembangan model baik dari sisi kategori, persentase, kualifikasi maupun tindak lanjut.

\section{Hasil Penlitian dan Pembahasan Deskripsi Hasil}

Hasil analisis terhadap data pengukuran/ identifikasi kebutuhan pengembangan model kepemimpinan efektif di SMP Negeri se-Kecamatan Konda diketahui bahwa selain model yang ditawarkan dipandang sebagai salah satu alternatif panduan untuk mengefektifkan kepemimpinan kepala sekolah, juga dimensi dan indikatorindikatornya merupakan sesuatu yang bersifat mutahir serta amat diperlukan. Pernyataan ini dapat dipahami sebab semua yang disyaratkan bagi seorang pemimpin efektif tercakup di dalamnya. Ini diperkuat oleh pernyataan bahwa model kepemimpinan yang baik atau efektif itu memiliki karakteristik cerdas, berpengalaman, jujur, stabil emosi, mampu bekerjasama, mampu berkomunikasi dengan baik, wirausahawan, terampil mengambil keputusan, memiliki kemampuan teknis, adil, percaya diri, suka mengayomi, penuh inovasi dan kreasi, ulet dan tahan uji, bergairah dalam bekerja, mawas diri, rendah hati dan objektif. Hal ini juga didukung oleh hasil bahwa model yang ditawarkan dapat diterapkan dengan mudah di sekolah meskipun perlu waktu untuk dapat melihat hasilnya.

Hasil analisis validitas dan reliabilitas instrumen yang diolah dengan menggunakan Microsoft excel diketahui bahwa kadar validitas instrumen lebih besar dari nilai $\mathbf{r}$ tabel 0,16504 , pada alpha 0,05 pada db $n-2$ atau $142-2$ atau $n=$
140 dan kadar realibilitasnya adalah 0,958 dengan galat baku sebesar 2,26 yang diperoleh melalui pengolahan Program MINITAB 14. Dengan demikian maka konsistensi hasil pengukuran pada kondisi yang berbeda dengan kondisi pelaksanaan pengukuran ini hanya akan mengalami peningkatan ataupun penurunan nilai yang masih mungkin terjadi adalah peningkatan sebesar 2,26 atau penurunan nilai sebesar 2,26 dari nilai yang ada. Artinya jika dalam suatu kesempatan peneliti melakukan penilaian keefektifan kepemimpinan kepala sekolah dengan menggunakan instrumen ini, maka jika hasil yang dicapai saat ini adalah $80 \%$ maka hasil yang akan dicapai pada kesempatan lain adalah paling tinggi $82,6 \%$ atau paling rendah $77,74 \%$. Dengan analisis seperti di atas, diketahui pula bahwa butir instrumen yang valid sebanyak 118 butir dan butir yang tidak valid (gugur) sebanyak 24 butir. Ketentuan untuk menentukan butir yang valid dan gugur mengikuti kaidah sebagai berikut: jika nilai korelasi total dari suatu item instrumen berada dibawah atau sama dengan 0,16504 maka butir instrumen tersebut dinyatakan gugur. Sebaliknya jika nilai korelasi total suatu item instrumen lebih besar dari 0,16504 maka instrumen tersebut dinyatakan valid. Demikian juga karena kadar reliabilitas instrumen mendekati 1 (satu) maka reliabilitas instrumen sangat baik.

Berdasarkan data dan hasil analisis validasi model konseptual dapat diinterpretasikan bahwa adanya angka persentase rerata $97,9 \%$ dari penilaian validator menunjukkan bahwa model kepemimpinan kepala sekolah yang efektif yang ditawarkan kepada validator mendapatkan nilai yang sangat baik sehingga sudah dapat diterapkan di SMP Negeri se-Kecamatan Konda. Hal ini sangat berdasar sebab studi tentang model-model kepemimpinan yang dikembangkan selama ini tidak memiliki keunggulan seperti temuan hasil penelitian ini dimana penelitian ini selain menemukan empat dimensi kepemimpinan kepala sekolah efektif yakni entrepreneur, teladan, cerdas dan demokratis yang diakronimkan dengan ENTELCERDAS, juga dilengkapi dengan rumusan indikator dan uraian praktiknya masing-masing secara rinci sebagaimana yang tampak pada gambar. 


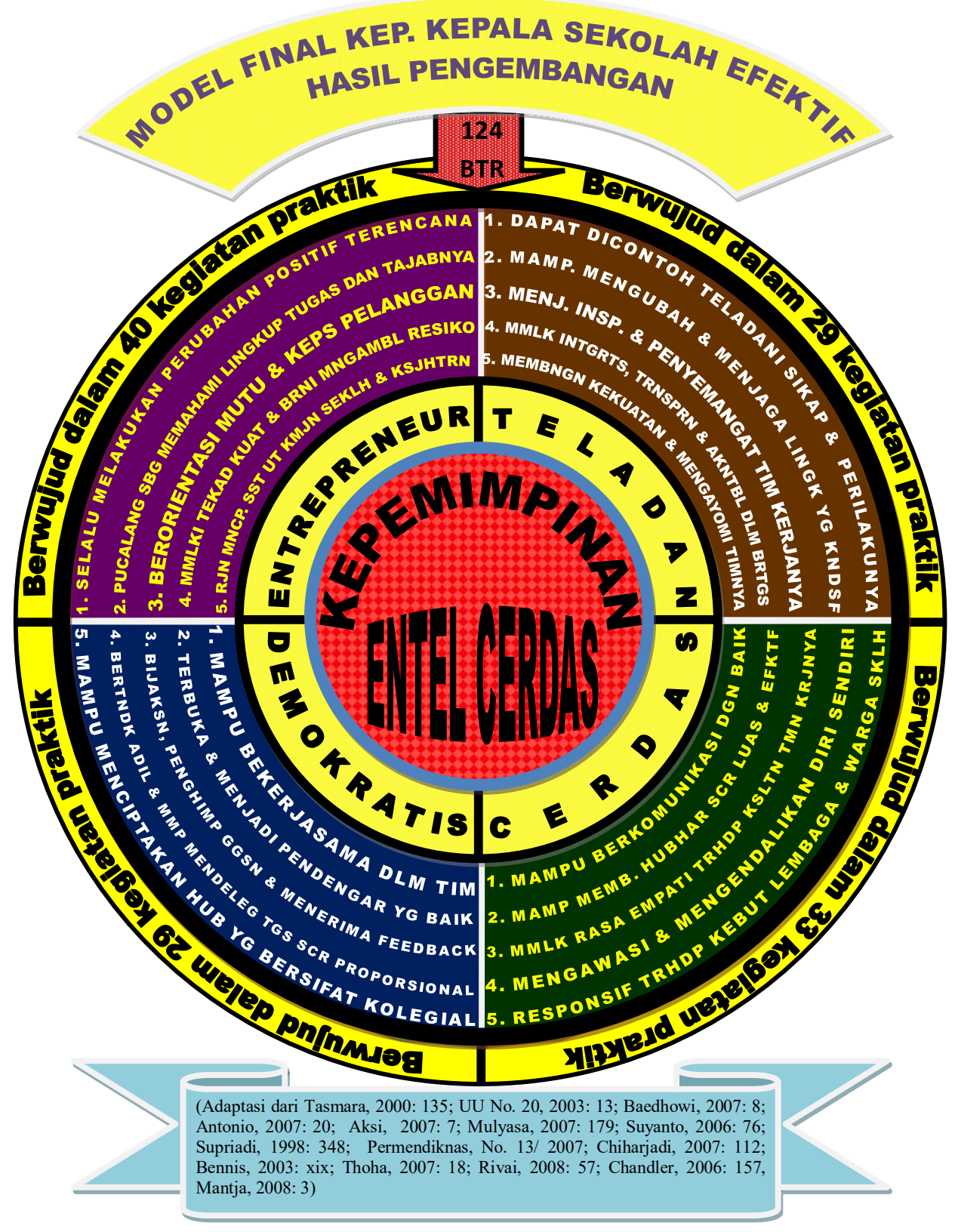

Gambar Model Final Kepemimpinan Kepala Sekolah yang Efektif

\section{Pembahasan}

Temuan seperti yang dideskripsikan di atas, sejalan dengan pandangan Fiedlre bahwa kepemimpinan efektif ditandai dengan uraian tugas yang rinci dan jelas baik yang berkaitan dengan vaiabel hubungan antara pimpinan dengan bawahan, variabel struktur tugas dan situasi kerja maupun variabel kekuasaan dan posisi (Fattah, 2008: 96). Jika dibandingkan dengan temuan penelitian pengembangan model kepemimpinan efektif seperti penelitian yang dilakukan oleh Ohio States University 1950, Michigan University 1967 pada dasarnya hanya menemukan bahwa Kepemimpinan efektif selain ditentukan oleh inistating structure (cara pemimpin melukiskan hubungannya dengan bawahan dalam menetapkan pola organisasi, saluran komunikasi, metode dan prosedur) and consideration (saling percaya, saling menghargai dan saling menjaga kehangatan antara pimpinan dengan bawahannya), juga menemukan bahwa keefektifan kepemimpinan ditandai oleh kadar resistensi (penolakan) bawahan terhadap pimpinan. Semakin tinggi resistensi semakin tidak efektif kepemimpinan dan semakin rendah resitensi semakin efektif kepemimpinan (Yukl, 2002: 49; Fattah, 2008: 92). Namun demikian indikator dan uraian butir indikator tentang 
inistating structure and consideration serta ressistance itu tidak diperoleh sehingga tetap menyisakan kesulitan dalam mengukur implementasinya. Demikian juga hasil penelitian pengembangan model MIN efektif yang dilakukan oleh Tanaka (2008: 85) hanya menemukan 7 kriteria MIN efektif dengan kualifikasi baik namun tidak menemukan sampai dengan uraian detail tentang Madrasah Ibtidaiyah Negeri efektif dalam wujud praktik yang dapat diukur baik oleh kepala sekolah sendiri maupun pihak lain secara jelas dan tepat.

Keunggulan lain dari temuan penelitian ini adalah kepala sekolah dapat dengan mudah mengecek pada dimensi mana yang mengalami kelemahan kepemimpinannya bahkan dapat mengetahui langsung pada indikator mana dan butir praktik mana yang mengalami kelemahan tanpa harus melakukan penelusuran yang lebih kompleks dan mendasar. Di samping itu, model kepemimpinan kepala sekolah hasil penelitian pengembangan ini juga dapat berfungsi sebagai pendorong bagi kepala sekolah untuk melakukan aksi perubahan jika sering membaca uraian implementasi praktiknya. Dengan temuan seperti itu maka model kepemimpinan kepala sekolah efektif ini juga dapat menjadi panduan praktis bagi para kepala sekolah yang menginginkan kepemimpinannya di sekolah menjadi efektif. Hal ini diperkuat oleh pernyataan bahwa keefektifan fungsi organisasi sekolah sangat dipengaruhi oleh dukungan bawahan dan panduan kepemimpinan yang jelas di tingkat sekolah (Sagala, 2008: 243).

Studi tentang pengembangan model kepemimpinan oleh Ohio States University menemukan instrumen untuk mendeteksi pelaksanaan tugas seorang pemimpin yang dikenal dengan LBDQ (Leader Behavior Description Questionaire) (Yukl, 2002: 50), penelitian ini juga menemukan instrumen implementasi model kepemimpinan kepala sekolah efektif dan tabel penilaian tentang keefektifan implementasi model yang disingkat dengan P- KIM. Karena itu temuan penelitian ini dapat dikatakan sangat applicable dan lebih praktis. Dengan hasil-hasil temuan seperti itu, maka penafsiran yang terpenuhi sesuai isi tabel tentang analisis, penafsiran data dan tindak lanjut validasi produk pengembangan model adalah: kategori 4, persentase 91-100, kualifikasi sangat baik dan tidak perlu direvisi. Hal ini memberi penegasan bahwa model kepemimpinan kepala sekolah yang efektif adalah kepemimpinan yang berpilarkan/berdimensikan entrepreneur, teladan, cerdas dan demokratis yang terdistribusi ke dalam 20 indikator kinerja dan terurai dalam 124 butir implementasi dalam bentuk praktik sebagaimana yang tampak pada produk final pengembangan model kepemimpinan kepala sekolah efektif beserta uraiannya.

Berdasarkan hasil analisis terhadap data tentang hasil uji coba terbatas implementasi model kepemimpinan kepala sekolah efektif dalam bentuk praktik dapat diinterpretasikan bahwa kepala sekolah di SMP Negeri pada Kecamatan Konda telah melaksanakan model kepemimpinan kepala sekolah efektif meskipun membutuhkan tindak lanjut peningkatan baik dalam arti kuantitas maupun kualitas. Kata-kata membutuhkan peningkatan mengisyaratkan agar dimensidimensi dimaksud diperbaiki dan ditingkatkan aplikasinya oleh kepala sekolah di masa-masa yang akan datang.

Kondisi seperti di atas menunjukkan bahwa meskipun model kepemimpinan kepala sekolah efektif hasil penelitian pengembangan ini memiliki banyak keunggulan dibanding dengan modelmodel kepemimpinan kepala sekolah yang lain, namun kenyamanan, keinginan, tekad bulat dan inovasi dari seorang kepala sekolah untuk mengimplementasikannya menjadi faktor yang turut berpengaruh terhadap kadar keefektifannya. Karena itu untuk memperkuat keberhasilan implementasi model kepemimpinan kepala sekolah ini, diperlukan tekad bulat, inovasi, kenyamanan dan mementingkan pelanggan dari seorang kepala sekolah (O'Neil, 2006: 271). Artinya kepala sekolah harus memiliki kesungguhan untuk melakukan perbaikan dan peningkatan terhadap segala hal yang belum terimplementasikan olehnya dalam memimpin sekolah dengan penuh rasa nyaman. Hal ini sejalan dengan pernyataan bahwa pemimpin yang baik selain harus selalu melakukan improvisasi, juga harus bertindak secara real time yang berarti tepat waktu dan tepat sasaran (Djalal, 2007: 12). Satu dari empat dimensi kepemimpinan kepala sekolah efektif yang telah terimplementasikan dengan sangat baik adalah dimensi demokratis. Ini menunjukkan bahwa dimensi itu memiki tingkat keterterapan yang tinggi. Karena itu perlu dipertahankan dengan sungguh-sungguh. 
Berdasarkan hasil interpretasi di atas, dapat direkomondasikan bahwa model kepemimpinan kepala sekolah efektif ini dapat dijadikan sebagai salah satu acuan untuk menciptakan kepemimpinan kepala sekolah yang efektif di sekolah. Karena itu tinggallah kemauan dari kepala sekolah untuk mengimplementasikannya atau tidak sebab kepemimpinan adalah kemampuan dan kemauan untuk mengerahkan segala SDM dan sumber daya selebihnya untuk mencapai tujuan. Kepemimpinan juga adalah proses mempengaruhi bawahannya untuk berkinerja sesuai dengan tujuan yang dikehendakinya (Manurung, 1995: 16). Dalam konteks yang sama kepemimpinan kepala sekolah efektif akan sangat menonjol kelihatan jika butir-butir yang berkaitan dengan kepengajaran diimplementasikan dengan baik. Hal ini sesuai dengan pernyataan bahwa agar kepala sekolah efektif dalam kepemimpinannya di sekolah maka salah satu kegiatannya adalah melakukan supervisi pembelajaran (Mantja, 2008: 93). Demikian juga hasil penelitian Painter 1980 pada 16 sekolah menengah diperoleh hasil bahwa sebahagian besar pendorong perbaikan di sekolah adalah perilaku supervisi yang dilakukan oleh kepala sekolah pada guru-guru. Karena itu Sergiovanni menekankan agar kepala sekolah selalu melakukan supervisi pembelajaran dengan pendekatan yang tepat baik direktif, nondirektif, kolaboratif, klinis dengan pola-pola demokratis (Mantja, 2008: 93).

Hal-hal seperti yang diungkapkan di atas sangat penting untuk dilakukan sebab penelitian inipun menemukan perlunya supervisi yang kontinyu dan terencana untuk perbaikan proses dan hasil pembelajaran. Bagaimanapun juga kualitas pembelajaran akan menentukan kualitas hasil out putnya nanti. Hal ini diperkuat oleh pernyataan bahwa domain organisasi pendidikan efektif adalah di samping merespon dan melakukan kegiatan rutin dalam pelaksanaan program, juga ada komitmen yang kuat untuk mencapai visi, misi dan tujuan serta target organisasi sebab kesuksesan adalah kinerja dan prestasi (Sagala, 2008: 249). Mengacu pada uraian pembahasan hasil penelitian dan pengembangan ini, dapat juga dikatakan bahwa keunggulan hasil penelitian ini sangat logis adanya sebab selain didukung oleh landasan teoretik yang kuat dan penelitian empirik yang relevan juga karena model yang ditemukan sangat relevan dengan kondisi sekolah yang menjadi sasaran penelitian serta sesuai pula dengan kebutuhan pendidikan dewasa ini.

\section{Simpulan dan Saran Simpulan}

Model kepemimpinan kepala sekolah yang efektif yang sesuai dengan kondisi SMP Negeri di Kecamatan Konda adalah kepemimpinan ENTELCERDAS, sebuah akronim dari entrepreneur, teladan, cerdas dan demokratis yang berisikan 20 indikator kinerja dan berwujud dalam 124 butir implementasi praktik dengan uraian sebagai berikut: a) Entrepreneur terdiri dari 5 indikator kinenerja kepemimpinan dan terurai dalam 40 $(36+4)$ butir wujud praktik; b) Teladan terdiri dari 5 indikator kinerja kepemimpinan dan terurai dalam $29(28+\mathbf{1})$ butir wujud praktik; c) Cerdas terdiri dari 5 indikator kinerja kepemimpinan dan terurai dalam $33(32+\mathbf{1})$ butir wujud praktik; d) Demokratis terdiri dari 5 indikator kinerja kepemimpinan dan teruraia dalam 22 butir praktik. Sementara deskripsi efektivitas perwujudan dimensi kepemimpinan INTELCERDAS kepala sekolah di SMP Negeri se-Kecamatan Konda saat ini dapat digambarkan sebagai berikut: a) Perwujudan entrepreneur secara rerata mencapai $84,8 \%$ dengan kualifikasi baik (efektif) dan tindak lanjutnya adalah pembenahan dan peningkatan di masa-masa yang akan datang, b) Perwujudan teladan secara rerata mencapai $80,5 \%$ dengan kualifikasi baik (efektif) dan tindak lanjutnya adalah pembenahan dan peningkatan, c) Perwujudan cerdas secara rerata mencapai $87,5 \%$ dengan kualifikasi baik (efektif) dan tindak lanjutnya adalah pembenahan dan peningkatan, d) Perwujudan demokratis secara rerata mencapai $91,8 \%$ dengan kualifikasi sangat baik (sangat efektif) dan tindak lanjutnya adalah dipertahankan. Adapun produk model kepemimpinan hasil penelitian pengembangan ini tersajikan sebagaimana pada halaman berikut ini.

\section{Saran}

Saran yang dikemukakan pada penelitian ini yaitu: kiranya kepemimpinana entelcerdas (entrepreneur, teladan, cerdas, demokratis) dapat diimplementasikan oleh semua kepala SMP Negeri di Kecamatan Konda, kiranya para kepala SMP Negeri di Kecamatan Konda dapat membenahi segera aspek-aspek dari wujud praktik implemen- 
tasi kepemimpinan kepala sekolah efektif yang memiliki aspek-aspek kelemahan sehingga kepemimpinannya dapat lebih efektif, kiranya pihak Dinas Pendidikan Konsel dapat mensosialisasikan model kepemimpinan kepala sekolah efektif ini di sekolah-sekolah yang sederajat terutama kepada sekolah yang memiliki karakteristik yang sama dengan SMP Negeri Kecamatan Konda, dan kiranya para peneliti yang lain dapat menjadikan model kepemimpinan kepala sekolah efektif hasil penelitian pengembangan ini sebagai bahan informasi dalam rangka penelitian pengembangan tentang model kepemimpinan efektif di sekolah dalam konteks yang berbeda.

\section{Pustaka Acuan}

Akil. 2006. Peranan Kepemimpinan Kepala Sekolah dalam Meningkatkan Motif Berprestasi Tenaga

Kependidikan dan Pengaruhnya terhadap Prestasi Belajar Siswa SLTP Negeri Kabupaten

Indramayu. (Http://www.malang.ac.id/jurnal. Akses, 27 Juni 2008).

Aksi. 2007. Peran Starategis Kepala Sekolah Dalam Meningkatkan Mutu Pendidikan. Jatinangor: Alqaprint Jatinangor.

Anonim. 2002. Kamus Besar Bahasa Indonesia. Jakarta: Balai Pustaka.

Anwar. 2007. Manajemen Pemberdayaan Perempuan. Bandung: Alfabeta.

Arikunto, Suharsimi. 2001. Dasar-Dasar Evaluasi Pendidikan. Jakarta: Bumi Aksara.

Borg, R. Walter \& Gall, Meredith D. 1989. Educational Research An Introduction. New York: Meredit Damien Gall.

Djalal, Dino Patti. 2007. Harus Bisa, Seni Mempin Ala SBY. Jakarta: R\&W.

Fattah, Nanang. 2008. Landasan Manajemen Pendidikan. Bandung: Remaja Rosda Karya.

Keputusan Menteri Pendidikan Nasional No.162/U/2003. Tentang Pedoman Penugasan Guru sebagai Kepala Sekolah. Jakarta: Depdiknas.

Mantja, Willem. 2008. Profesionalisasi Tenaga Kependidikan: Manajemen Pendidikan dan Supervisi Pengajaran. Malang: Elang Mas.

Manurung, M. R. 1995. Manajemen Keluarga. Bandung: Indonesia Publishing House.

Moleong, Lexy J. 2000. Metodologi Penelitian Kualitatif. Bandung: Remaja Rosda Karya.

Mutohir, Cholik Toho dan Alimaksum. 2007. Sport Development Index (Konsep, Metodologi dan Aplikasi). Jakarta: Indeks.

Nurkolis. 2003. Manajemen Berbasis Sekolah. Grasindo: Jakarta.

O’Neil, J. William. 2006. Successful Business Leaders. Jakarta: Bhuana Ilmu Populer.

Rivai, Veithzal. 2008. Kepemimpinan dan Perilaku Organisasi. Jakarta: Raja Grafindo Persada.

Riyanto, Yatim. 2001. Metodologi Penelitian Pendidikan. Surabaya: SIC.

Rothwell, J.William. 1995. Practicing Organization Development. San Diego California: Pfeiffer \& Company.

Sagala, Syaiful. 2008. Budaya dan Reinventing Organisasi Pendidikan. Bandung: Alfabeta.

Subagioatmodiwirio. 2000. Manajemen Pendidikan Indonesia. Ardadizya Jaya: Jakarta.

Suderadjat, Hari. 2005. Manajemen Peningkatan Mutu Berbasis Sekolah. Bandung: Cipta Cekas Grafika. Sugiyono. 2004. Statistika Untuk Penelitian. Bandung: Alfabeta.

--------. 2007. Metode Penelitian Kuantitatif, Kualitatif dan R \& D. Bandung: Alfabeta.

Sukmadinata, Syaodih. Nana. 2005. Metode Penelitian Pendidikan. Bandung: Remaja Rosda Karya.

Supriadi, Dedi. 1998. Mengangkat Citra dan Martabat Guru. Yogyakarta: Adi Cita Karya Nusa.

Syafaruddin. 2002. Manajemen Mutu Terpadu Dalam Pendidikan Konsep, Strategi, dan Aplikasi. Jakarta: Grasindo.

Tanaka, Ahmad. 2008. "Pengembangan Model Madrasah Efektif (Studi pada MIN Kolaka)". Tesis Magister pada PPs Unhalu, tidak diterbitkan.

Tilaar, H.A.R. 2001. Beberapa Agenda Reformasi Pendidikan Nasional Dalam Prespektif Abad 21. Jakarta: Indonesia Tera.

Wahyudi. 2009. Kepemimpinan Kepala Sekolah Dalam Organisasi Pembelajar. Alfabetha: Bandung.

Yukl, Gary. 2002. Leadership in Organizations. State University of New York at Albany: Prentice Hall. 